\title{
"Taking it for granted": The utilization of pragmatic aspects in entertainment news reporting on Instagram
}

\author{
Alya Khalisah and Harwintha Yuhria Anjarningsih* \\ English Study Program, Department of Linguistics, Faculty of Humanities, Universitas Indonesia, \\ Jl. Profesor Dr. Selo Soemardjan, Depok, Indonesia
}

\begin{abstract}
Instagram has been one of the main platforms for real-time information seeking for the last five years (Schroeder, 2018). The kind of information that people look for includes entertainment news. The present study aims to examine the way an entertainment news account presents its news content using different pragmatic techniques and how these techniques affect its brand image because minor attention has been paid to purpose-oriented accounts. To fulfill the aim, there are two research problems that are addressed: (1) what are the most common pragmatic techniques used in the captions? And (2) what significance does each technique have in presenting the news and shaping the brand image? Therefore, 36 sample captions from E! News Instagram account, as the most followed entertainment news account on Instagram, were taken, observed, and analyzed using a framework developed by Al-Hindawi and Mehdi (2017) in their article about a pragmatic analysis on American and British website-based entertainment news that focuses on three pragmatic pillars, namely presupposition, Grice's conversational maxims, and allusion. The study found that in the case of E! News, presupposition, violation to Grice's conversational maxims, and allusion are not merely used to keep the content interesting, but they respectively hold important roles in shaping the content of the news, engaging audience's interest, and creating a good brand image.
\end{abstract}

Keywords: Allusion; brand image; conversational maxims; entertainment news; Instagram; presupposition

\begin{tabular}{|c|c|c|}
\hline $\begin{array}{l}\text { First Received: } \\
8 \text { September } 2019 \\
\text { Final Proof Received: } \\
\text { 14 January 2020 } \\
\end{array}$ & $\begin{array}{c}\text { Revised: } \\
19 \text { November } 2019\end{array}$ & $\begin{array}{c}\text { Accepted: } \\
\text { 7 December } 2019 \\
\text { Published: } \\
\text { 31 January 2020 }\end{array}$ \\
\hline $\begin{array}{l}\text { How to cite (in APA style): } \\
\text { Khalisah, A. \& Anjarningsih, H. } \\
\text { pragmatic aspects in entertai } \\
\text { Applied Linguistics, } 9,508-5\end{array}$ & $\begin{array}{l}\text { 020). "Taking it fo } \\
\text { nt news reporting c } \\
\text { doi: } 10.17509 / \text { ijal.v }\end{array}$ & $\begin{array}{l}\text { ted": The utilization of } \\
\text { tagram. Indonesian Journal of } \\
200\end{array}$ \\
\hline
\end{tabular}

\section{INTRODUCTION}

The rise of social media has changed the way people communicate and obtain information. In the case of personal usage, social media enable people to monitor what others are doing (Schroeder, 2018) and build or maintain good contact with the people they care about. At the same time, seeking information online is ranked as equally important as socializing in social media (Schroeder, 2018). To fulfill the need for obtaining information, purpose-oriented accounts, such as news accounts, campaign accounts, or philanthropic accounts, emerged in many different social media platforms, one of them is Instagram. As the sixth most popular social media platform in the world (Statista, 2019), preceded by Facebook and Youtube, with more or less 1 billion active users, Instagram also holds an essential role in spreading information to people all over the world. News accounts, in particular, are spreading widely in this platform. Many news companies that used to post their news content on websites or blogs are making their way to Instagram. These include entertainment news accounts, and among them are the popular ones in the United States of America which are eonline.com, etonline.com, cosmopolitan.com, usmagazine.com, tmz.com, and many more.

\footnotetext{
* Corresponding Author

Email: wintha.salyo@gmail.com
} 
Different from regular news accounts, an entertainment news account aims not only at reporting one issue or one event but also at amusing the audience (Al-Hindawi \& Mehdi, 2017). Consequently, different aims necessitate different techniques, as well. In reporting entertainment news, it is mandatory to always present the post in an up-to-date, edgy, and modern manner because the audience of this kind of news is usually younger generations (Schroeder, 2018). However, keeping this kind of content interesting in social media platforms like Instagram might require different tricks compared to what is done on websites.

Instagram upholds the image of aesthetics, realtimeness, and conciseness. Examining the pictures and words it represents might be of interest to researchers who examine social media through a semiotic perspective. However, to understand the characteristics of the linguistic styles in entertainment news reports on Instagram, a pragmatic approach may be the most suitable to dig deeper into the meaning and intention. It is considered important to do this because several previous studies focus mostly on the linguistic styles of personal accounts. Olorunlenke, Obidiran, and Mustafa (2017) discovered two politeness strategies in the use of invective language on Facebook. This kind of technique is used to express feelings and emotions more clearly because social media is limited in terms of displaying gestures and non-verbal aspects of communication. Continued by Matley (2017), the study focused on the pragmatic of hashtags used by Instagram users and found that Instagram users engage in face-threatening behavior and, in fact, are aware of the danger it poses. Thus, they also apply the politeness strategy in their posts to save their self-image. Furthermore, ten kinds of expositive acts that help in creating users' selfrepresentations are also found in Instagram captions, according to a journal article written by Amirudin and Triyono (2018).

All these journal articles showed one similar finding: different kinds of pragmatic techniques are prevalent on personal accounts, and these techniques hold an important role in shaping the self-representation of the users. Then, these questions appear:

- Are there different pragmatic techniques in celebrity news reports on Instagram?

- If there are, does each technique hold particular roles in shaping the account's brand image?

Therefore, this research will focus on discussing the pragmatics of entertainment news reports on Instagram, specifically on the E! News Instagram account. The paper chose the E! News Instagram account in particular because it is the most followed entertainment news account on Instagram. To be specific, there are approximately 11.9 million followers worldwide on this account, per November 2018. With that huge number of followers, it is proven that there are many people in different parts of the world who pay attention to this account. Hence, it is interesting to understand how E! News stands out from other entertainment news accounts in Instagram in terms of the number of the followers, and one way to understand this phenomenon is by studying further about the news content they created that attract people to read and follow the account.

Accordingly, the study aims to see whether there is a specific pragmatic technique used in this kind of platform and whether that technique conceivably plays a role in shaping the brand image of E! News. The brand image of business entities is "emotions, ideas or attitudes that customers associate with the entities" (Erkmen \& Hancer, 2018). In the case of E! News Instagram account, the brand image is possibly emotions, ideas, or attitudes that the followers keep in their minds that drive them to follow the account. Furthermore, this paper is aimed to contribute research about pragmatics in social media, especially in purposeoriented accounts that are still rarely done up to this day. To fulfill these goals, posts from E! News Instagram account are collected, observed, and analyzed to see whether the account applies presupposition and allusion, and violates the conversational implicature in writing the captions using a framework developed by Al-Hindawi and Mehdi (2017), which is explained later in this paper.

Potts (2014) argued that presupposition is purely the speaker's action since it is the previous assumptions that the speakers have made before talking to the audience. Presupposition, as Potts (2014) argued, "Cannot easily be traced to specific words or phrases, but rather seem to arise from more general properties of the context and the expectations of the discourse participants." Indeed, Barbulet (2013) stated that there are four critical aspects of context, which are: (a) preceding and following utterances and/or expressions ('co-text'), (b) the immediate physical situation (in spoken communication), (c) the wider situation, including social and power relations (who write and what the purpose is), and (d) knowledge presumed shared between speaker and hearer.

Up to this point, it is safe to say that presupposition cannot stand or function on its own without context. Now, consider what Huang (2007) said about presupposition. A presupposition is used as the precondition that helps create a context in a sentence (Huang, 2007). In short, presupposition and context are closely related to one another. Among different kinds of presupposition, there are only two that will be the focus of this paper, namely the existential presupposition and factive presupposition. The first one, existential presupposition or some call it definite presupposition may include proper names, possessives, and certain whphrases (Huang, 2007), for example:

Freddy Mercury died because of AIDS.

$\rightarrow$ Freddy Mercury exists.

On the other hand, factive presupposition can be divided into two types which are those triggered by 
prior knowledge and those triggered by the emotional attitude towards fact, for example:

\section{Example 1:}

We know about Jenna Dewan and Channing Tatum split.

$\rightarrow$ Jenna Dewan and Channing Tatum have split.

\section{Example 2:}

Ariana Grande regrets not paying attention to her late ex-boyfriend, Mac Miller, before his death.

$\rightarrow$ Ariana did not pay attention to her late exboyfriend, Mac Miller, before his death.

\section{Conversational implicature}

According to Grice (1989), as cited in Huang (2007), "There is an underlying principle that determines the way in which language is used with maximum efficiency and effectiveness to achieve rational interaction in communication." This implies that there is always something to be analyzed within the language; no matter how simple it is. In his book, Huang (2007) provides a simplified explanation for Grice's conversational implicature theory, and it looks like this:

A. The co-operative principle $\rightarrow \mathrm{Be}$ cooperative.

B. The maxims of conversation:

- Quality: Be truthful. (i) Don't say what is false. (ii) Don't say what lacks evidence.

- Quantity: (i) Don't say less than is required. (ii) Don't say more than is required.

- Relation: Be relevant.

- Manner: Be perspicuous. (i) Avoid obscurity. (ii) Avoid ambiguity. (iii) Be brief. (iv) Be orderly.

According to Davis (2010), as cited in Potts (2014), the maxim of social media posts should be "Stylish, beautiful, distinctive, entertaining, and interesting," which gives pressure to the person who creates the caption. The maxim, thus, gives them the chance to violate manner and perhaps other maxims, for example, by using slang and catchphrases to help construct a particular social identity, or in the case of purpose-oriented accounts, to help build their brand image.

\section{Allusion}

As cited from Al-Hindawi and Mehdi's (2017) research, an allusion is an indirect reference that gives the reader a clearer image or explanation about a person, a place, or a thing. Allusion does not come in the form of a full explanation, but rather a brief comment, be it words or phrases that the speakers expect the readers to have prior knowledge about. These are some examples of allusion retrieved from Al-Hindawi and Mehdi (2017):

\section{Example 1:}

"This place is like a Garden of Eden."

$\rightarrow$ This is a biblical allusion so that the listener can imagine the situation of the place as similar to the Garden of God.

\section{Example 2:}

"Stop acting like my ex-husband please."

$\rightarrow$ It is also impossible to make an allusion from common place or people.

As seen from the two examples, the allusion is based strongly on shared knowledge, background assumptions, mutual manifestness, and common sense knowledge. It can also give negative or positive meaning to the place, person, or thing being referred to. For instance, the first example gives a positive meaning to the place because it is comparable with the peaceful and beautiful atmosphere of the Garden of Eden. However, the second example gives the negative meaning for the person being referred to because of the phrase "stop acting like ..." which means that probably the ex-husband had a bad attitude that should not be followed by the listener of this utterance.

The following is dedicated to discussing the theoretical framework developed by Al-Hindawi and Mehdi (2017) in their journal article about the pragmatic of a celeb news report in USA and UK websites. The paper combines qualitative and quantitative analysis because it does not only provides textual analysis but also statistically calculates the findings of the analysis. The model they developed basically analyze the pragmatic aspects of celebrity and entertainment news reports from three big pillars, which are presupposition, allusion, and conversational maxim. The research also gives an argument for each theory that is discussed, so it is not merely stating that all the pragmatic techniques have the same function, which is to present the news in "tip-top" shape.

The first thing that Al-Hindawi and Mehdi (2017) did in their research paper was introducing the source of their data, which were BBC News (UK based) and Entertainment Tonight (USA based). Then they collected sample celebrity news reports from both accounts and observed them using the three pillars. Since the sources were websites, the data collection took a lot of space, so the writers only put 10 samples in the primary textual analysis. These samples were analyzed in this order: 3 samples were analyzed for their significant use in presupposition, 3 samples for their use in allusion, and 4 samples for their use in conversational maxims. After that, the paper counted which pragmatic aspect appeared most often on all the sample news reports they had collected. To present the data, the writers included two tables that showed the frequency rate and the total percentage of each pragmatic aspect used. This qualitative analysis was used to support the hypothesis of the paper, which stated that presupposition was the aspect that was highly utilized in British and American celebrity news reporting.

Taking the model developed by Al-Hindawi and Mehdi (2017), the schemes of this paper are: (1) analyzing the presupposition that is frequently found in the captions, focusing specifically on existential and 
factive presupposition, (2) analyzing conversational maxims in the captions of E! News Instagram account through which maxim they infringed and what kind of maxim that they used, and (3) understanding how the use of allusion, whether it is direct or indirect references, helps giving meaning to the captions and to build the brand image of E! News. However, this paper does not focus on the frequency rate nor the percentage of each aspect because the aim of this paper is more to understand what the specific role of each pragmatic aspect in celebrity news reporting on Instagram is, and how it is being utilized by the most followed American entertainment news account on Instagram.

\section{METHOD}

A qualitative method was used in this study because it provided an easier approach to textual data, and it was suitable for the theme of the research. The research itself did not focus on the frequency of the appearance of each pragmatic element; instead, it focused more on how it was used in the text. In collecting the data, this research started by observing the E! News Instagram account. After a thorough observation, approximately 102 captions containing the phrase "click the link in bio" were taken because these were the captions that had the actual news content on eonline.com. Next, 36 captions were eventually chosen due to them being in the categories that E! News most often reported in their account. These were news about celeb relationships, music and movie releases, and celeb conflicts. The category of celeb conflicts covered news or information other than (normal and problematic) romantic consensual relationships, such as sexual assaults and social media war. Then from each category, one sample was taken from every month, starting from October 2017 to September 2018. As a result, each category had 12 samples. If combined, there were 36 samples collected from the three categories.

In the Findings and Discussion part, the samples were analyzed based on which pragmatic techniques they applied, just like the framework that was discussed before.

\section{FINDINGS AND DISCUSSION \\ Are there different pragmatic techniques in celebrity news reports on Instagram? \\ To answer the first research question of this paper, it is important to confirm that, on E! News Instagram account, there are indeed three frequent pragmatic techniques used in the captions which are presupposition (found in 14 captions), violation to Grice's conversational maxims (found in 6 captions), and allusion (found in 16 captions). There were some captions that contained more than one pragmatic technique (11 captions), and there were 11 captions that did not contain any pragmatic techniques. In Table 1 , a breakdown of the number of techniques found in each of the categories is presented.}

Table 1. Classification of pragmatic techniques in the sample captions

\begin{tabular}{lccc}
\hline \multirow{2}{*}{ Pragmatic techniques } & \multicolumn{3}{c}{ Categories } \\
\cline { 2 - 4 } & $\begin{array}{c}\text { Celebrity } \\
\text { relationship }\end{array}$ & $\begin{array}{c}\text { Music \& movie } \\
\text { release/promo }\end{array}$ & $\begin{array}{c}\text { Celebrity conflicts/ } \\
\text { divorce }\end{array}$ \\
\hline Presupposition & 7 & 5 & 2 \\
Violation of Grice's maxims & 1 & 0 & 5 \\
Allusion & 8 & 5 & 3 \\
\hline
\end{tabular}

Table 1 shows that the category celebrity relationship made use of presupposition, the violation of Grice's maxims, and allusion. The category of celebrity conflicts \& divorce also made use of the three techniques, but the category of music \& movie release/promo did not make use of violations to Grice's conversational maxims.

The following captions are examples of captions that contained presupposition (a complete list of all the captions is in Appendices 1 and 2).

1 E! News Tenews 1 (November 2017)

A picture says a thousand words, but Zayn and Gigi Hadid aren't spending more than just one night together exclusivelv. Click the link in our bio for why she's hesitant to let Zayn be her man...again. (t): TheImageDirect) [Instagram Post 1 Retrieved from https://instagram.com/enews

2 E! News [enews] (July 2018)

We've been so caught up in the whirlwind romance of Pete \& Ariana that we forgot she was also going through a breakup--Until Mac Miller reminded us with a new song. Link in bio for the drama. (ㅇ: GC Images) [Instagram Post] Retrieved from https://instagram.com/enews

These two examples apply existential and factive presuppositions in the texts. In Example 1, the reporters expected the audiences to know that Zayn and Gigi Hadid exist as persons (existential) and as a couple who have just recently rekindled their romance after a short breakup (factive). Similarly, Example 2 shows that the reporters presuppose that the audiences knew the existence of Pete Davidson and Ariana Grande (existential), and the fact that they are dating (factive). This second example also shows the fact that Ariana Grande used to have a relationship with Mac Miller in the past, and how this conflict still affects Ariana's current relationship status.

Existential presupposition can easily be found in entertainment news. Every report that contains names signals that the reporters assumed the audience have already known who they are talking about. By taking 
this, they can be creative with their caption. For instance, when talking about Jamie Dornan in example 3 , the reporters can easily make an allusion from the movie he starred in because they are sure that the audience knows the existence of Jamie Dornan.

3 E! News [enews] (Februarv 2018)

Jamie Dornan will see you now...on the Fifty Shades Freed soundtrack, that is. Head to the link in bio to listen to his rendition of Maybe I'm Amazed. (ㅇ: Alex Berliner/AB Images) Retrieved from https://instagram.com/enews

Another example is in sample example 4 in which the report talks about Travis Scott, and the reporters also presupposed that the audience knows who Travis Scott is. Therefore they make an allusion from one of his most popular song lyrics titled Goosebumps.

4 E! News [enews] (August 2018)

Travis Scott's album Astroworld dropped yesterday, and it's clear he has a muse with multiple references to Kylie Jenner and S tormi. And we get those goosebumps EVERY TIME. Link in bio for the details. (o Swan Gallet/WWD/REX/S hutterstock)

Patterns like this can be found in almost every caption that the E! News writes. Among those in Appendix 1 are sample 6A, 7A, 9A, 11A, 12A, 2B, and 12B.

On the other hand, factive presupposition may be a bit tricky to find because it depends on certain adjectives or verbs that determine the attitude towards the news. For instance, in sample 1C, the verb "refused" gives a negative tone towards the news. The same thing happens in sample 8A where the adjective "hesitant" gives more explanation about how Gigi Hadid feels towards getting back with Zayn Malik. From there, the audience can presuppose that they may or may not get back together. Last but not least, in the sample $7 \mathrm{C}$, the phrase "the day love truly died" indicates how many people worship the relationship between Jenna Dewan and Channing Tatum. Therefore, the audience who did not really follow the development of their relationship can presuppose that Jenna Dewan and Channing Tatum used to have a very fulfilling, romantic marriage that everyone looked up to.

The next captions contain a violation of Grice's conversational maxims.

$5 \quad$ E! News [enews] (December 2017)

Congratulations to Chanel Iman and Sterling Shepard on their engagement! The Giants wide receiver proposed to the supermodel at the couple's home in New Jersey last night on her 27th birthday. 8 Link in bio for their happy news. (to: @chaneliman) [Instagram Post] Retrieved from https://instagram.com/enews

6 E! News [enews] (S eptember 2018)

Mia Bally and Tristan Thompson (no, not Khloe's Tristan) had a LOT of ups and (mostly) downs on Married At First Sight, but now they've officially divorced. The full story is at the link in bio. (o: Lifetime/Kinetic Content)

\begin{tabular}{lll}
$\begin{array}{l}\text { [Instagram } \quad \text { Post }\rceil \\
\text { https://instagram.com/enews }\end{array}$ & Retrieved & from \\
\hline
\end{tabular}

Example 5 violates the maxim of relation because the second sentence, "The Giants wide receiver proposed to the supermodel at the couple's home in New Jersey last night on her 27th birthday," uses another nickname for the couple which is "The Giants Wide Receiver" and "The Supermodel" when it actually has no relationship with the engagement news. Likewise, example 6 puts the phrase "No, not Khloe's Tristan" when the news content itself does not talk about Khloe Kardashian nor his husband, Tristan Thompson. Instead, it talks about another celeb with the same name as Khloe Kardashian's husband, Tristan Thompson. Patterns like this also appear in sample 5C and 9C (see Appendices 1 and 2). The phrase "For the full story on this modern family, visit the link in bio" that relates to Julie Bowen in sample 5C, and the phrase "For God's plan visit the link in our bio" that relates to Drake has nothing to do with the news being reported in each caption

7 E! News [enews] (March 2018)

Vanderpump Rules' Lala Kent isn't too happy about Jennifer Lawrence calling her a "c--t" on live TV. Kent wrote in tweets that have since been deleted: "B---h, you better pray I don't see you in the streets." For all the tea, visit the link in bio. [Instagram Post] Retrieved from https://instagram.com/enews

This one violates the maxim of quantity because it is certainly enough to only mention the name Lala Kent and still report the news. However, the reporter chose to put "Vanderpump Rules" as the (unnecessary) extra information about the TV series in which Lala Kent is one of the actresses. Besides this example, this pattern can also be seen in sample $2 \mathrm{C}$ when the writer mentioned the name Naya Rivera preceded by "Glee" which is the TV series she starred in. Even though the report does not talk about Glee at all, the writer still chose to mention it to make people relate easier to the person being reported.

The last example of captions contain allusion.

8 E! News [enews] (January 2018)

We're seeing 50 shades of Yellow: Chris Martin and Dakota Johnson spent a day in Malibu with their arms wrapped around one other and it looked like they were in para-para-paradise. Head to the link in bio for the full story. ( 0 : DOBN / RMBI / BACKGRID) [Instagram Post] Retrieved from https://instagram.com/enews

$9 \quad$ E! News [enews] (May 2018)

Shawn Mendes' third album has dropped and he has set the record straight on his relationship status: He's single. If there's nothing holding you back, visit the link in bio. (이: JB Lacroix/WireImage) [Instagram Post] Retrieved from https://instagram.com/enews

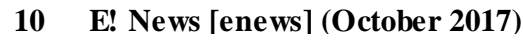

A wedding is coming for Joe Jonas and Sophie Turner: They just announced that they're 
engaged! Link in bio for the full story. ( 0 : Raymond Hall/GC Images) [Instagram Post] Retrieved from https://instagram.com/enews

$1111 \mathrm{E}$ ! News [enews] (September 2017)

Mia Ballv and Tristan Thompson (no. not Khloe's Tristan) had a LOT of ups and (mostly) downs on Married At First Sight, but now they've officially divorced. The full story is at the link in bio. (Lifetime/Kinetic Content)

Regarding allusion, for example, in 8 , the phrase "We are seeing 50 shades of Yellow" is doing a double job of making allusion to both Dakota Johnson and Chris Martin. Johnson was the main female character in the movie 50 Shades of Grey (2015), and "Yellow" was the title of one of Coldplay's most famous songs. Coldplay is the band in which Chris Martin takes the role as the lead singer. The phrase "para-para-paradise" in the last part of the caption also makes direct reference to one of Coldplay's songs, Paradise. The next example shows how allusion is used in the news about music album release by Shawn Mendes. The phrase "if there's nothing holding you back" alludes to one of Shawn Mendes hit song titled "There's Nothing Holding Me Back" which was released in 2017. Next, in example 10 which is about celeb engagement news, the phrase "A wedding is coming for Joe Jonas and Sophie Turner" makes a direct reference to Sophie Turner because the quote "A (noun) is coming" came from the title of the first episode in the first season of Game of Thrones, Winter is Coming, a series in which Turner holds one of the important roles. Last but not least, in example 11, which is under the category celebrity conflicts/divorce, the title Married at First Sight alludes to the television program where Mia Bally and Tristan Thompson once starred. Patterns like this can also be shown in Appendix 1 and Appendix 2 from samples 6A, 9A, 11A, 12A, 2B, and $12 \mathrm{~B}$.

If there are, does each technique hold particular roles in shaping the account's brand image?

In the following, some possible roles of the techniques found in the sample captions are put forward. We propose also possible repercussions of the techniques to the company's brand image. In general, presupposition contributes a sense of succinctness in the news, violation of Grice's conversational maxims gives attractiveness to the news, and allusion contributes a sense of modernity that oftentimes is intertwined with casualness.

\section{Presupposition}

Just like any other news, E! News as the most followed entertainment news platform on Instagram also benefits from the use of two types of presupposition, which are existential presupposition and factive presupposition.

Regarding presupposition, from examples 1 up to 4 and Table 1, it is proven that presupposition is the tool that keeps the news report concise. Presupposition may be more closely related to celeb relationship, and music/movie release, but less closely related to celeb conflict. This relatedness may be due to the wish to build a brand image that is more to the point or serious regarding celebrity conflict news.

\section{Violation of Grice's conversational maxims}

The concept of Grice's conversational maxims basically demands the speaker to say only what really needs to be said. However, entertainment news content may violate the theory of Grice's conversational maxims. It typically happens in entertainment news reports because the reporters have the agenda to also entertain the audience and not merely reporting the news. Here, the research provides a discussion about how news reports in $\mathrm{E}$ ! News Instagram account violates the maxims of quality, quantity, manner, and relation in order to keep the content informative while at the same time attractive.

As seen from the evidence, examples 5 and 6 imply that violation of maxims is used to give variation, so that audience who read this will not be bored when reading the caption and examples 7 and 8 imply that violation of maxims is used to emphasize the person or the thing being reported about. Therefore, the violations were used most probably to catch the audience's attention when reading the news as the trick that keeps news reports interesting.

\section{Allusion}

Of course, a big entertainment news reporting company like E! News wants the audience to have a good impression of their brand image. That is why language variations are significant in their caption. This one technique, which is the use of allusion, might be the essential technique that plays a vital role in shaping the account's brand image.

Allusion can indeed help E! News to show how updated they are as an entertainment news account. Therefore, it shaped E! News brand image as up-to-date and very modern. However, using allusion may also create the mood of joking and being casual, instead of serious. Fortunately, E! News knows how to properly use this particular tool. The three examples above $(8,9$, and 10) show how the E! News applied a good amount of allusion in "happier" kinds of news. On the other hand, there is a big difference when it comes to reporting a more serious form of news, for instance, celeb conflict, in example 11.

As can be observed, there is minimum playful use of allusion in celeb conflict reports in the E! News Instagram account. Besides these examples, from the Appendices, 3 out of 12 samples in the Conflicts/ divorce category use minimum allusion. There are only samples $8 \mathrm{C}$ and 10C, in which both of them still use allusions from song lyrics and $12 \mathrm{C}$ in which it alludes to a television show who may not have been directly involved with the news being reported. The caption in this kind of news tends to go in detail about the chronology of the conflict, instead of excessively using allusion. This trick, in a way, conceivably gives a good image for the E! News because it makes them seem like 
they know where to put allusion and when to distinguish which type of news can be given allusion and which ones are not.

Arguably, these possible roles of the pragmatic techniques in shaping the E! News account's brand image may be seen as just proposed roles because multidisciplinary studies with the fields of marketing and communication need to be carried out (e.g., Gökerik, Gürbüz, Erkan, Mogaji, \& Sap, 2018). It is indeed conceivable that brand image built by social media accounts is a complex entity that is the interplay among customers' behaviors/beliefs, companies' marketing strategies, and factors in the accounts themselves (including linguistic factors). However, the results of the current study are an indispensable contribution in investigations of purpose-oriented accounts since only minimal attention in the literature has been paid to them in this regard and may be seminal in proposing professionalism in purpose-oriented accounts. The results may also complement findings from managerial research aiming at measuring brand image (e.g., Plumeyer, Kottemann, Böger, \& Decker, 2019).

\section{CONCLUSION}

This paper has stated three main suggestions about the uses of different kinds of pragmatic techniques, which are presupposition, the violation of Grice's conversational maxims, and allusion that contribute to the observation of E! News' popularity on Instagram. In previous studies, it is mentioned that pragmatic techniques are used just to build the brand image of the company. However, it is important to note that in the Findings and Discussion section, it has been shown that each technique may actually create different results. Presupposition, on its own, is used to keep the content of the news brief, and that is important for news account on Instagram since there is limited space. This is contrary to the intentional violation of Grice's conversational maxims. The violation comes in the form of adding irrelevant or unnecessary information, but not to the extent of putting harsh or rude words, or in other words, violates the maxims of manner to grab the audience's attention. Last but not least, the allusion in a way gives the feeling of modernity, which is mandatory for accounts like E! News because this not only builds a good brand image but also boosts their credibility as well. Despite those claims, it is important to note that this study does not pay attention to the number of likes and the comment section. Images that are uploaded along with the posts, the time when the posts are made public, and the demographic details of the followers are similarly not controlled in the study. The analysis above is primarily based on the theory and the analysis of language style and word choice that appear in the caption. Hence, it is recommended for future research to take those variables into account to get a more accurate understanding of how the usage of the three pragmatic techniques gives an impact on the brand image of the company.

\section{REFERENCES}

ENEWS Instagram. (2019, April 9). Retrieved from eonline.com: https://www.eonline.com/

Al-Hindawi, F. H., \& Mehdi, M. K. (2017). A Pragmatic Approach to American and British Entertainment and Celeb News Report. British Journal of English Linguistics, 5(2), 29-50.

Amirudin, A., \& Triyono, S. (2018). Expositive Acts on Instagram: Knowing What People Intent to "Write" on their Captions through Pragmatics Perspective . International Journal of Applied Linguistics \& English Literature, 7(4), 129-137. doi: 10.7575/aiac.ijalel.v.7n.4p.129

Barbulet, G. (2013). Social Media- A pragmatic Approach: Contexts \& Implicatures. Procedia Social and Behavioral Sciences, 83, 422-426. doi: 10.1016/j.s bs pro.2013.06.083

Erkmen, E. \& Hancer. M. (2018). Building brand relationship for restaurants. International Journal of Contemporary Hospitality Management, 31(3), 1469-1487. doi: 10.1108/ijchm-08-2017-0516

Gökerik, M., Gürbüz, A., Erkan, I., Mogaji, E., \& Sap, S. (2018). Surprise me with your ads! The impacts of guerrilla marketing in social media on brand image. Asia Pacific Journal of Marketing and Logistics, 30(5), 1222-1238. doi: 10.1108/apjml10-2017-0257

Huang, Y. (2007). Pragmatics. New York: Oxford University Press.

Matley, D. (2017). "This is NOT a \#humblebrag, this is just a \#brag": The pragmatics of self-praise, hashtags and politeness in Instagram posts. Dsicourse, Context, and Media, 22, 30-38. doi: 10.1016/j.dcm.2017.07.007

Olorunlenke, S. F., Obidiran, G., \& Mustafa, L. J. (2017). Pragmatic Analysis of Invective Language on Social Media . International Journal od Research and Development, 6(10) 128-134. doi: 10.24940/ijird/2017/v6/i10/sep 17076

Plumeyer, A., Kottemann, P., Böger, D., \& Decker, R. (2019). Measuring brand image: a systematic review, practical guidance, and future research directions. Review of Managerial Science, 13(2), 227-265. doi: 10.1007/s 11846-017-0251-2

Potts, C. (2014). Presupposition and Implicature. Stanford Linguistics .

Schroeder, R. (2018). Social Theory After the Internet. London: UCL Press.

Statista (2019). Most popular social networks worldwide as of October 2019, ranked by number of active users (in millions). Retrieved from https://www.statista.com/statistics/272014/globalsocial-networks-ranked-by-number-of-users/ 


\section{APPENDIX 1}

E! News Instragram Captions October 2017 - March 2018

\begin{tabular}{|c|c|c|c|c|c|c|}
\hline Classification & Sample 1 (Oct 17) & Sample 2 (Nov 17) & Sample 3 (Dec 17) & Sample 4 (Jan 18) & Sample 5 (Feb 18) & Sample 6 (Mar 18) \\
\hline 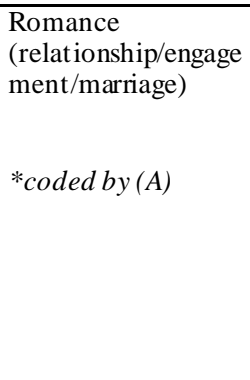 & $\begin{array}{l}\text { A wedding is coming for Joe } \\
\text { Jonas and Sophie Turner: } \\
\text { They just announced that } \\
\text { they're engaged! Link in bio } \\
\text { for the full story. (o: } \\
\text { Raymond Hall/GC Images) }\end{array}$ & $\begin{array}{l}\text { Zayn Malik and Gigi Hadid } \\
\text { have been loving each other } \\
\text { from dusk till dawn for the } \\
\text { past two years and we can’t } \\
\text { help but celebrate with them. } \\
\text { Head to the link in bio for a } \\
\text { look back at their relationship. } \\
\text { (o: @ gigihadid / } \\
\text { Shut terstock/ Getty Images } \\
\text { / @ zayn) }\end{array}$ & $\begin{array}{l}\text { Congratulations to Chanel } \\
\text { Iman and Sterling Shepard on } \\
\text { their engagement! The Giants } \\
\text { wide receiver proposed to the } \\
\text { supermodel at the couple's } \\
\text { home in New Jersey last night } \\
\text { on her 27th birthday. } 8 \text { Link } \\
\text { in bio for their happy news. } \\
\text { @ @ chaneliman }\end{array}$ & $\begin{array}{l}\text { We're seeing } 50 \text { shades of } \\
\text { Yellow: Chris Martin and } \\
\text { Dakota Johnson spent a day in } \\
\text { Malibu with their arms } \\
\text { wrapped around one other and } \\
\text { it looked like they were in } \\
\text { para-para-paradise. Head to } \\
\text { the link in bio for the full } \\
\text { story. ( : DOBN / RMBI/ } \\
\text { BACKGRID) }\end{array}$ & $\begin{array}{l}\text { We have some good news and } \\
\text { we have some bad news: The } \\
\text { bad news is, Idris Elba is } \\
\text { officially off the market (we } \\
\text { know (-) but the good news } \\
\text { is that he and girlfriend } \\
\text { Sabrina Dhowre are officially } \\
\text { engaged, and there's video } 8 \\
\text { Visit the link in bio to watch } \\
\text { the proposal. ( }: \text { Getty } \\
\text { Images) }\end{array}$ & $\begin{array}{l}\text { Nick Jonas was spotted } \\
\text { kissing someone sexy } \\
\text { beautiful and it's our right to } \\
\text { be hellish, we still get jealous. } \\
\text { Link in our bio for more } \\
\text { details on his Australian } \\
\text { vacation with Annalisa } \\
\text { Azaredo. ( Mega) }\end{array}$ \\
\hline $\begin{array}{l}\begin{array}{l}\text { Music \& movie } \\
\text { release/promotions }\end{array} \\
\text { *coded by }(B)\end{array}$ & $\begin{array}{l}\text { Episode } 100 \text { of The Walking } \\
\text { Dead airs tonight. Take a look } \\
\text { at how the cast has changed } \\
\text { throughout the past } 8 \text { years } \\
\text { and head to the link in our bio } \\
\text { for the full list. ( }: \text { : AMC) }\end{array}$ & $\begin{array}{l}\text { Ed Sheeran released his } \\
\text { Perfect music video and } \\
\text { proves one thing: He is an } \\
\text { angel and we don't deserve it. } \\
\text { Link in bio for the full video. } \\
\text { ( } \text { @ TeddysPhotos) }\end{array}$ & $\begin{array}{l}\text { Hold up: Ed Sheeran and } \\
\text { Beyonce's Perfect duet is here } \\
\text { and we don't deserve it-link } \\
\text { in bio to listen....and maybe } \\
\text { cry. ( : Kevin } \\
\text { Winter/Wirelmage) }\end{array}$ & $\begin{array}{l}\text { Just in Timberlake will always } \\
\text { be the President of Pop, but } \\
\text { starting Friday he'll also be } \\
\text { known as the Man of the } \\
\text { Woods. Head to the link in } \\
\text { bio for more on his upcoming } \\
\text { single and album release. } \\
\text { (@: @ JustinTimberlake) }\end{array}$ & $\begin{array}{l}\text { Jamie Dornan will see you } \\
\text { now...on the Fifty Shades } \\
\text { Freed soundtrack, that is. } \\
\text { Head to the link in bio to } \\
\text { listen to his rendition of } \\
\text { Maybe I'm Amazed. ( Alex } \\
\text { Berliner/AB Images) }\end{array}$ & $\begin{array}{l}\text { The first trailer for } \\
\text { the \#WreckItRalph sequel is } \\
\text { here and we'd personally like } \\
\text { to welcome him to the land of } \\
\text { memes. Head to the link in } \\
\text { bio or the full trailer for Ralph } \\
\text { Breaks The Internet: Wreck-It } \\
\text { Ralph } 2 \text {. } \\
\text { (o: @ Disney Animation) }\end{array}$ \\
\hline $\begin{array}{l}\text { Conflicts/divorce } \\
\text { *coded by }(C)\end{array}$ & $\begin{array}{l}\text { Gwyneth Paltrow and } \\
\text { Angelina Jolie have come } \\
\text { forward with sexual assault } \\
\text { allegations against Harvey } \\
\text { Weinstein. Angelina claims } \\
\text { Harvey made un wanted } \\
\text { sexual advances toward her in } \\
\text { a hotel room in the '90s and } \\
\text { never worked with him again. } \\
\text { Gwyneth refused Harvey's } \\
\text { advances on her at just } 22 \\
\text { years old and was "expected } \\
\text { to keep the secret." Link in } \\
\text { bio for the full story. } \\
\text { (o: @ GettyEntertainment) }\end{array}$ & $\begin{array}{l}\text { Just a month aftercalling off } \\
\text { her divorce from husband } \\
\text { Ryan Dorsey, Glee's Naya } \\
\text { Rivera has been arrested and } \\
\text { charged with misdemeanor } \\
\text { domestic battery. Head to the } \\
\text { link in our bio for the full } \\
\text { story. ( : Getty Images) }\end{array}$ & $\begin{array}{l}\text { It's over for Long Island } \\
\text { Medium's Theresa Caputo and } \\
\text { her husband of } 28 \text { years, } \\
\text { Larry Caputo } \$ \text {. Visit the } \\
\text { link in our bio for the full } \\
\text { story. ( : Getty Images) }\end{array}$ & $\begin{array}{l}\text { An exposé on James Franco } \\
\text { has been published that } \\
\text { details sexual misconduct } \\
\text { allegations made by five } \\
\text { women, including four former } \\
\text { students and one mentee. } \\
\text { Head to the link in bio for the } \\
\text { full story. ( : Zach } \\
\text { Pagano/NBC) }\end{array}$ & $\begin{array}{l}\text { Julie Bowen and husband } \\
\text { Scott Phillips are going their } \\
\text { separate ways after } 12 \text { years } \\
\text { of marriage. } \\
\text { story on this moder the full } \\
\text { visit link in bio. ( } \text { : Getty, } \\
\text { Images) }\end{array}$ & $\begin{array}{l}\text { Vanderpump Rules' Lala } \\
\text { Kent isn't too happy about } \\
\text { Jennifer Lawrence calling her } \\
\text { a "c--t" on live TV. Kent } \\
\text { wrote in tweets that have } \\
\text { since been deleted: "B---h, } \\
\text { you better pray I don't see you } \\
\text { in the streets." For all the tea, } \\
\text { visit the link in bio. }\end{array}$ \\
\hline
\end{tabular}


APPENDIX 2

E! News Instragram Captions October 2017 - March 2018

\begin{tabular}{|c|c|c|c|c|c|c|}
\hline Classification & Sample 7 (Apr 18) & Sample 8 (May 18) & Sample 9(Jun 18) & Sample 10(Jul 18) & Sample 11 (Aug 18) & Sample 12 (Sept 18) \\
\hline $\begin{array}{l}\begin{array}{l}\text { Romance } \\
\text { (relationship/enga } \\
\text { gement/marriage) }\end{array} \\
\text { *coded by (A) }\end{array}$ & $\begin{array}{l}\bullet \quad \text { Riverdale's Lili } \\
\text { Reinhart and Cole Sprouse } \\
\text { are just as sweet as Blossom } \\
\text { Maple Syrup. Sorry, } \\
\text { Archiekins. Link in bio for } \\
\text { details on their Paris trip! (6: } \\
\text { Best Image/Backgrid) }\end{array}$ & $\begin{array}{l}\text { A picture says a thousand } \\
\text { words, but Zayn and Gigi } \\
\text { Hadid aren't spending more } \\
\text { than iust one night together } \\
\text { exclusively. Click the link in } \\
\text { our bio for why she's hesitant } \\
\text { to let Zayn be her man... again. } \\
\text { ( : TheImageDirect) }\end{array}$ & $\begin{array}{l}\text { We're so into this possible } \\
\text { engagement ring that we can } \\
\text { barely breathe. Link in bio for } \\
\text { all we know about this rock } \\
\text { that appeared on Ariana } \\
\text { Grande's finger earlier this } \\
\text { month. (1: Getty Images) }\end{array}$ & $\begin{array}{l}\text { He asked and she said yes: } \\
\text { David Foster and Katharine } \\
\text { McPhee are engaged! } § \\
\text { Head to the link in bio for the } \\
\text { full st ory. ( }: \text { Kevin } \\
\text { Mazur/WireImage) }\end{array}$ & $\begin{array}{l}\text { Someone alert the capitol } \\
\text { because this couple is in a } \\
\text { district all their own. Link } \\
\text { in bio for more on Jennifer } \\
\text { Lawrence and Cooke } \\
\text { Maroney's romance. ( The } \\
\text { Image Direct) }\end{array}$ & $\begin{array}{l}\text { Halsey may say she's bad at } \\
\text { love, but in the end it's her } \\
\text { and G-Eazy. Head to the link } \\
\text { in bio for more on Halsey's } \\
\text { surprise appearance at G- } \\
\text { Eazy's concert, complete with } \\
\text { a crotch grab and a kiss. ( }: \\
\text { Deadboltphotos.com; Manny } \\
\text { Carabel/Getty Images) }\end{array}$ \\
\hline $\begin{array}{l}\text { Music \& movie } \\
\text { release/promotions }\end{array}$ & $\begin{array}{l}\text { Janelle Monaé has released } \\
\text { her latest single titled Pynk } \\
\text { and it just might be the } \\
\text { paradise found. Head to the } \\
\text { link in bio to see the female } \\
\text { anatomy-focused music video } \\
\text { feat uring Tessa Thompson. } \\
\text { ( @ @ janellemonae) }\end{array}$ & $\begin{array}{l}\text { Shawn Mendes' third album } \\
\text { has dropped and he has set the } \\
\text { record straight on his } \\
\text { relationship status: He's } \\
\text { single. If there's nothing } \\
\text { holding you back, visit the } \\
\text { link in bio. ( : JB } \\
\text { Lacroix/Wirelmage) }\end{array}$ & $\begin{array}{l}\text { Here is a baby with eyes of } \\
\text { blue, straight from heaven, } \\
\text { right to you. The first trailer } \\
\text { for \#Dumbo is here and we } \\
\text { weren't prepared to be crying } \\
\text { this much this early in the } \\
\text { morning. Watch the video at } \\
\text { the link in bio. ( Disney) }\end{array}$ & $\begin{array}{l}\text { We've been so caught up in } \\
\text { the whirlwind romance of } \\
\text { Pete \& Ariana that we forgot } \\
\text { she was also going through a } \\
\text { breakup--Until Mac Miller } \\
\text { reminded us with a new song. } \\
\text { Link in bio for the drama. (\$: } \\
\text { GC Images) }\end{array}$ & $\begin{array}{l}\text { Travis Scott's album } \\
\text { Astroworld dropped } \\
\text { yesterday, and it's clear he has } \\
\text { a muse with multiple } \\
\text { references to Kylie Jenner and } \\
\text { Stormi. And we get those } \\
\text { goosebumps EVERY TIME. } \\
\text { Link in bio for the details. } \\
\text { (o: Swan } \\
\text { Gallet/WWD/REX/Shuttersto } \\
\text { ck) }\end{array}$ & $\begin{array}{l}\text { - We're at a } \\
\text { payphone trying to call home } \\
\text { to tell everyone } \\
\text { that \#Maroon5 is performing } \\
\text { the \#SuperBowl Halftime } \\
\text { Show! The plans we made for } \\
\text { two are at the link in our bio! } \\
\text { ( } \text { ( : Wireimage) } \\
\text { comments Load more } \\
\text { - }\end{array}$ \\
\hline $\begin{array}{l}\text { Conflicts/divorce } \\
* \text { Coded by }(\mathrm{C})\end{array}$ & $\begin{array}{l}\text { Mark April 2nd, } 2018 \text { as the } \\
\text { day love truly died: Channing } \\
\text { Tatum and Jenna Dewan } \\
\text { Tatum have split after } 8 \text { years } \\
\text { of marriage. Click the link in } \\
\text { our bio for their official } \\
\text { statement. (ס: James } \\
\text { Gourley/REX/Shut terstock) }\end{array}$ & $\begin{array}{l}\text { And I ain't going nowhere } \\
\text { cause you're a keeper. Ariana } \\
\text { Grande and Mac Miller are } \\
\text { over. Link in bio for more on } \\
\text { their sudden split! ( } \text { : Kevin } \\
\text { Mazur/WireImage) }\end{array}$ & $\begin{array}{l}\text { • Pusha T and } \\
\text { Drake's feud has brought a lot } \\
\text { up, including Drake's alleged } \\
\text { child who he has been } \\
\text { financially supporting since } \\
\text { conception. For God's plan } \\
\text { visit the link in our bio. ( } \\
\text { Getty Images / Instagram) } \\
\text { - Load more } \\
\text { comments } \\
\text { - }\end{array}$ & $\begin{array}{l}\text { Where do broken hearts go? } \\
\text { Liam Payne and Cheryl are } \\
\text { going their separate ways- } \\
\text { click the link in our bio for his } \\
\text { full st atement confirming the } \\
\text { split. ( : Wireimage) }\end{array}$ & $\begin{array}{l}\text { There's a lot of tension } \\
\text { bet ween Kim and Kourtney, } \\
\text { especially after Kim said } \\
\text { Kourtney "just doesn't want to } \\
\text { be a Kardashian anymore." } \\
\text { Kourtney admits she's still } \\
\text { working on their relationship, } \\
\text { and the exclusive details are } \\
\text { in the link in bio. ( : Stephen } \\
\text { Lovekin/REX/Shutterstock) }\end{array}$ & $\begin{array}{l}\text { Mia Bally and Tristan } \\
\text { Thompson (no, not Khloe's } \\
\text { Tristan) had a LOT of ups and } \\
\text { (mostly) downs on Married } \\
\text { At First Sight, but now } \\
\text { they've officially divorced. } \\
\text { The full story is at the link in } \\
\text { bio. ( : Lifetime/Kinetic } \\
\text { Content) }\end{array}$ \\
\hline
\end{tabular}

